\title{
POLITIK HUKUM ISLAM DAN MAQASID AL-SYARIAH
}

\author{
Miskari \\ Sekolah Tinggi Agama Islam Mempawah \\ Jl.Gusti Sulung Lelanang,No 1,Mempawah Hilir,Kota Mempawah, Kalimantan Barat \\ Email : mahatthoh@gmail.com
}

\begin{abstract}
Abstrack: This study will discuss the Politics of Islamic law and maqashid sharia, where both meet at the same point, namely the benefit of the nation and the state and its people both in the world and in the hereafter. In order to realize the Islamic values of Islamic legal politics into real life, fukaha (Islamic law experts) launched a theory, among others, maqashid syari'ah (the objectives of Islamic law). The Maqashid Shari'ah aspect divides three complementary priority scales. First, dharury, as a necessity or necessity, is something that must exist for the sake of human life. If something doesn't exist, then human life will definitely be destroyed. The goals of the daruri are to save religion, soul, reason, property, descent and self-esteem (hurdles, pride or honor). For example, to save lives, the Qur'an instructs humans to eat, but they cannot overdo it. Second, Hajy, or needs, meaning, something is needed for the survival of human life. If something does not exist, then human life will not experience destruction, but difficulties will confront. Third, tahsiny, or decorative-ornamental processes. That is, the absence of decorative-ornamental matters will not destroy the purpose of dharury.
\end{abstract}

Keyword: Politics; Islamic Law; Maqashid Syariah

Abstrak: Penelitian ini akan membahas tentang Politik hukum Islam dan maqashid syariah, dimana keduanya bertemu pada titik yang sama yaitu kemaslahatan bagi bangsa dan negara serta rakyatnya baik di dunia maupun di akhirat nanti. Dalam rangka mewujudkan nilai-nilai Ilahiah politik hukum Islam ke dalam kehidupan nyata, fukaha (pakar hukum Islam) mencanangkan teori, antara lain, maqashid syari'ah (tujuan-tujuan hukum Islam). Aspek maqashid syari'ah membagi tiga skala prioritas yang saling melengkapi. Pertama, dharury, sebagai keharusan-keharusan atau keniscayaankeniscayaan, yaitu sesuatu yang harus ada demi kelangsungan kehidupan manusia. Jika sesuatu itu tidak ada, maka kehidupan manusia pasti akan hancur. Tujuan-tujuan daruri itu adalah menyelamatkan agama, jiwa, akal, harta, keturunan dan harga diri (hurmah, pride atau kehormatan). Misalnya, untuk menyelamatkan jiwa, Qur'an memerintahkan agar manusia makan, tetapi tidak boleh berlebihan. Kedua, Hajy, atau kebutuhan-kebutuhan, artinya, sesuatu dibutuhkan demi kelangsungan kehidupan manusia. Jika sesuatu itu tidak ada, maka kehidupan manusia tidak akan mengalami kehancuran, tetapi kesulitan-kesulitan akan menghadang. Ketiga, tahsiny, atau proses-proses dekoratifornamental. Artinya, ketiadaan hal-hal dekoratif-ornamental tidak akan menghancurkan tujuan dharury.

Kata Kunci : Politik; Hukum Islam; Maqashid Syariah

AL-IMARAH: Jurnal Pemerintahan dan Politik Islam 
AL-IMARAH: Jurnal Pemerintahan dan Politik Islam Vol. 4, No. 1, 2019

\section{Pendahuluan}

Islam adalah agama yang komperhensif. Harun Nasution mengatakan bahwa Islam itu mencakup berbagai aspek kehidupan manusia mulai dari aspek aqidah (teologi), hukum (syari'at), falsafah, akhlaq (tasawuf), hingga aspek politik. Islam bukan agama sempit, yang hanya mengatur aspek ritual peribadatan. Aspek-aspek kehidupan manusia di atas ada yang diatur oleh wahyu dengan aturan-aturan yang detail hingga petunjuk teknisnya seperti aspek ibadah mahdhah (shalat, haji, aspek hukum). Namun, ada pula aspek yang wahyu Allah itu hanya memberikan pedoman umum saja, sedangkan tata cara, teknis dan prosedurnya diserahkan oleh wahyu kepada umat Islam untuk melakukan ijtihad, ${ }^{1}$ salah satu contohya dalam hal ini adalah politik dalam ajaran Islam.

Perkembangan teori-teori politik hukum Islam sangat jelas dan benar adanya. Teori-teori ini, terutama pada fase-fase pertumbuhan pertamanya-berkaitan erat dengan kejadiankejadian sejarah Islam sehingga hal itu harus dilihat seakan-akan keduanya adalah dua sisi mata uang atau dua bagian yang saling melengkapi.

Paradigma integralistik ini yang kemudian melahirkan paham negara-agama, di

\footnotetext{
${ }^{1}$ Nasution, Harun, Islam Ditinjau dari Aspeknya, Jilid I dan II (Jakarta: UI-Press, 1979), h. 11. 58
}

mana kehidupan kenegaraan diatur dengan menggunakan Prinsip-prinsip keagamaan, sehingga melahirkan konsep Islam din wa dawlah (Islam agama dan sekaligus negara). Sumber hukum positifnya adalah sumber hukum agama. Masyarakat tidak bisa membedakan mana aturan negara dan mana aturan agama karena keduanya menyatu. Oleh karena itu, dalam paham ini, rakyat yang menaati segala ketentuan negara berarti ia taat kepada agama, sebaliknya, memberontak dan melawan negara berarti melawan agama yang berarti juga melawan Tuhan.

Negara dengan model demikian tentu saja sangat potensial terjadinya otoritarianisme dan kesewenang wenangan penguasa, karena rakyat tidak dapat melakukan kontrol terhadap penguasa yang selalu berlindung di balik agama. Karena sifatnya yang demikian, maka para penulis Barat sejauh dikaitkan dengan islam, sering melihat negara agama tidak compatible dengan demokrasi. Demokrasi yang berangkat dari paharn antroposentnis meniscayakan manusia menjadi pusat segala selaga peradaban dunia.

Dalam agama Islam ada aturan, hukum dan budaya menjadi pedoman utama kehidupan umat Islam secara keseluruhan, mulai dari halhal yang individu untuk urusan sosial masyarakat pada umumnya. Apakah syariat, yang mengatur hukum dan digunakan sebagai pedoman dalam kehidupan seluruh umat 
manusia. Sebagai aturan hidup memiliki tujuan utama untuk dapat diterima oleh semua umat manusia. Tujuan menurunkan hukum Islam adalah untuk kebaikan seluruh umat manusia. Dalam lingkup tujuan ini disebut ushul fiqh dengan maqashid syariah maksud yaitu dan tujuan dari wahyu hukum Islam

Islam memiliki konsep rahmatan lil'alamin artinya adalah Islam mengutamakan nilai-nilai manfaat dalam mengatur obyek diatur. Dengan konsep ini Islam mengatur bagaimana manusia harus hidup sosial, sehingga untuk menciptakan perdamaian, kehidupan yang harmonis, adil dan makmur. Penerapan konsep ini dimaksudkan untuk menjadi hubungan antara individu, masyarakat, dan bahkan antar negara meskipun mapan, saling hak dan kewajiban terpenuhi dan bahwa tidak ada kepentingan partai terdzalimi oleh kepentingan lainnya. karakter rahmatan Islam lil 'Alamin juga menjadi solusi permasalahan yang timbul karena perbedaan mendasar dalam kehidupan masyarakat, seperti dalam kasus keyakinan, ras, budaya, fisik, dll Islam telah dimasukkan juga manusia yang tidak percaya pada Allah sebagai Tuhannya, menengahi perbedaan dengan sangat sederhana dan mudah dimengerti. ${ }^{2}$

Dalam rangka mewujudkan nilai-nilai Ilahiah poltik hukum Islam ke dalam kehidupan

\footnotetext{
2 Novi Rizki Amalia dalam artikelnya yang berjudul "Penerapan Konsep Maqashid Syariah Untuk Realisasi Identitas Politik Islamdi Indonesia" diunduh pada tanggal 12-01-2019
}

nyata, fukaha (pakar hukum Islam) mencanangkan teori, antara lain, maqashid syari'ah (tujuan-tujuan hukum Islam). Mereka merumuskan bahwa tujuan hukum Islam adalah menyelamatkan manusia dari dunia sampai akhirat. Salah satu aspek maqashid syari'ah membagi tiga skala prioritas yang saling melengkapi, yaitu primer (dharury), sekunder (hajy), dan tersier (tahsiny).

Dalam kaitan inilah dalam sejarah politik hukum Islam, negara dan pemerintahan yang pertama dapat diamati dengan dua pendekatan. Pertama, pendekatan normatif Islam yang menekankan pada pelacakan terhadap nas-nas, Alquran dan sunah nabi yang mengisyaratkan adanya praktek pemerintahan yang dilakukan oleh nabi dalam rangka siyasat syar'iyyah. Kedua, pendekatan deskriptifhistoris dengan mengidentikkan tugas-tugas negara dan pemerintahan.

Sebagaimana diketahui, kehadiran politik (sebagai metode untuk menguasai pemerintahan), dalam pandangan Islam bukanlah tujuan utama (ghayah), melainkan sebagai sarana untuk enggapai tujuan (wasilah). ${ }^{3}$ Sama halnya dengan syariat (agama), tujuannya adalah untuk menggapai kemaslahatan dan menolak kemudharatan untuk bangsa dan negara (maqashid syariah). Hal ini diperjelas oleh Syamsuddin Ramadhan

3 Afifuddin Muhajir, Fiqh Tata Negara. (Yogyakarta, IRCiSoD : 2017). h. 23 
AL-IMARAH: Jurnal Pemerintahan dan Politik Islam Vol. 4, No. 1, 2019

mengutip pendapat Al-Mawardi yang menegaskan bahwa kepemimpinan negara merupakan instrument untuk meneruskan misi kenabian guna memelihara agama dan mengatur dunia. Pemeliharaan agama dan pengaturan merupakan dua jenis aktifitas yang berbeda, tetapi berhubungan secara simbolik. Keduanya merupan dua dimensi dari misi kenabian. ${ }^{4}$

Menurut pandangan Islam, benar atau tidaknya sebuah kebijakan pemipin atau penyelenggara pemerintahan bergantung pada implikasinya terhadap rakyat. Jika kebijakan tersebut berimplikasi pada kemaslahatan rakyat maka dianggap benar oleh syariat. Sebaliknya, jika kebijakan tersebut berdampak mafsadat pada rakyat maka dianggap menyalahi syariat. Sebuah kebijakan harus membuahkan kemaslahatan karena seorang pemimpin bekerja tidak untuk dirinya, melainkan sebagai wakil dari rakyat yang dipimpinnya. ${ }^{5}$

Oleh sebab itu, ummat Islam haru faham politik sehingga tidak hanya menjadi komuditas atau alat politik semata. Sehingga tujuan berpolitik dan beragama akan menemui titik temu dalam bingkai maqashid syariah (tujuantujuan syariah). Karenanya, dirasa penting untuk membahas hubungan antara politik hukum Islam dan Maqashid syariah.

\footnotetext{
${ }^{4}$ Syamsuddin Ramadhan, Menegakkan Kembali Khilafah Islamiyah. (Jakarta: Panjimas, 2003), h. 45

${ }^{5}$ Afifuddin Muhajir, h 91
}

\section{A. Politik Hukum Islam}

1. Pengertian Politik Hukum

Sebelum membahas secara menyeluruh tentang politik hukum Islam dan maqashid syariah, sebaiknya kita fahami dulu tentang politik hukum. Menurut Warkum Sumitro $\mathrm{dkk}^{6}$, secara etimologis, istilah politik hukurn adalah kata terjemahan dan bahasa Belanda recht politiek yang berasal dan dua kata, recht dan politiek. Recht berarti hukum. Kata politiek dalam kamus hahasa Belanda memiliki pengertian beleid. Kata beleid dalarn bahasa Indonesia memiliki arti kebijakan (policy). Dengan demikian politik hukum bisa diartikan kebijakan hukum. Adapun kebijakan sendiri dalam bahasa Indonesia berarti rangkaian konsep dan asas yang menjadi garis besar dari dasar rencana dalam pelaksanaan suatu pekerjaan, kepemimpinan dan cara bertindak. Dalam hal ini politik hukum dapat diartikan rangkaian konsep dan asas yang menjadi garis besar dari dasar rencana dalam pelaksanaan suatu pekerjaan, kepemimpinan dan cara bertindak dalam bidang hukum. ${ }^{7}$

Sedangkan definisi politik hukum secara terminologi menurut beberapa ahli strategi politik adalah sebagai berikut :

1. Teuku Mohammad Radhie

\footnotetext{
${ }^{6}$ Warkum Sumitro, dkk, Politik Hukum Islam (Malang, UB Press : 2014 ), h 13

${ }_{7}$ Imam Syaukani dan Ahsin Tohari, DasarDasar Politik Hukum,( Jakarta: Raja Grafindo : 20013 ), h. $19-25$
} 60 
Teuku Mohammad Radhie mendefinisikan politik hukurn sebagai suatu pernyataan kehendak penguasa negara mengenai hukurn yang berlaku di wilayahnya (ius constitutum) dan mengenai arah perkembangan hukum yang dibangun (ius constituendum)

\section{Satjipto Rahardjo}

Satjipto Rahardjo mendefinisikan politik hukum sebagai aktivitas memilih dan cara yang hendak dipakai untuk mencapai tujuan sosial dan hukum tertentu dalam masyarakat. Dalam terminology ini, politik hukum mencakup beberapa pertanyaan mendasar sebagai herikut :

a. Tujuan apa yang hendak dicapai dalarn sistern hukum yang ada

b. Cara-cara apa dan yang mana yang dirasa paling baik untuk mencapai tujuan tersebut.

c. Kapan hukurn itu harus diubah dan dengan cara apa perubahan itu dilakukan.

d. Dapatkah dirumuskan suatu pola yang baku dan mapan yang bisa membantu kita memutuskan proses pemilihan tujuan serta cara-cara untuk mencapai tujuan tersebut secara baik. ${ }^{8}$

3. Padmo Wahjono

Dalam pandangan Padmo Wahjono politik hukum diartikan sebagai kebijakan dasar yang menentukan arah, bentuk maupun isi dan hukum yang akan dibentuk. Dalam kesempatan lain Padmo Wahjono juga memberikan arti

\footnotetext{
${ }^{8}$ Sajipto Rahardjo, limu Hukum, (Bandung: Citra Aditya Iakti : 2001), h 352
}

politik hukum adalah kebijakan penyelenggara negara tentang apa yang dijadikan kriteria untuk rnenghukumkan sesuatu. Ruang lingkup dan terminology ini mencakup pembentukan hukum, penerapan hukurn dan penegakannya.

Dari sini dapat disimpulkan bahwa definisi politik hukum menurut Padmo Wahjono adalah kebijakan penyelenggara negara yang bersifat mendasar dalam menentukan arah bentuk maupun isi dari hukurn yang akan dibentuk dan tentang apa yang dijadikan kriteria untuk menghukumkan sesuatu. Dalam hal ini sepertinya politik hukum lebih diorientasikan pada hukum yang berlaku di masa yang akan datang (ius constituendum). Hal tersebut nampak berbeda dengan definisi yang diungkapkan Radhie yang lebih mengorentasikan kepada persoalan ius constium dan lus Constituendum

\section{C.F.G. Sunaryati Hartono}

Dalam terminologi politik hukum beliau menjelaskan bahwa secara eksplisit bahwa politik hukurn sebagai sebuah alat atau sarana dan langkah yang dapat digunakan oleh pemerintah urituk menciptakan sistem hukum nasional itu akan diwujudkan cita-cita bangsa Indonesia .

\section{Abdul Hakim Garuda Nusantara}

Politik hukum secara harfiah dapat diartîkan sebagai kebijakan hukurn (legal policy) yang hendak diterapkan atau dilaksanakan secara nasional oleh suatu 
AL-IMARAH: Jurnal Pemerintahan dan Politik Islam Vol. 4, No. 1, 2019

pemerintah negara tertentu. Dengan demikian, politik hukum bergerak pada penguasaan terhadap suatu pemerintahan guna mengatur kehidupan berbangsa dan bernegara agar tercipta kehidupan yang damai dan aman dengan adanya aturan hukum yang jelas dan tegas terhadap para pelanggar hukum tanpa membedakan dari suku, ras, agama, dan golongan tertentu.

\section{Mahfud MD}

Politik hukum merupakan legal policy atau garis (kebijakan) resmi tentang hukurn yang akan diberlakukan baik dengan pembuatan hukum baru atau penggantian hukum lama, dalam rangka mencapai tujuan negara. Dengan demikian, politik hukum merupakan pilihan tentang hukum-hukum yang akan diberlakukan sekaligus pilihan hukum-hukum yang akan dicabut atau tidak diberlakukan yang kesemuanya dimaksudkan untuk mencapai tujuan negara seperti yang tercantum dalam pembukaan UUD 1945). ${ }^{9}$

Politik hukum baru yang berisi upaya pembaruan hukum menjadi keharusan ketika pada tanggal 17 Agustus 1945 Indonesia diprokiamasikan sehagai Negara merdeka dengan UUD 1945 sebagai hukum dasarnya. Proklamasi kemerdekaan menuntut pembaruan atau penggantian atas hukum-hukum peninggalan zaman penjajahan Jepang dan

9 Mahfud MD, Politik Hukum di Indonesia, (Jakarta: Rajawali Perss, 2011), h. 1 62
Belanda, sebab jika dilihat dari tata hukum maka proklamasi kemerdekaan merupakan tindakan perombakan secara total. Proklamasi kemerdekaan telah membawa Indonesia pada idealita dan realita hukum yang lain dan sebelumnya. Proklamasi kemerdekaan telah mengubah tradisi masyarakat dan keadaan terjajah menjadi masyarakat bebas (merdeka). Tujuan hukum pun harus berubah secara kebalikan dari tujuan mempertahankan dan melestarikan penjajahan menjadi mengisi kemerdekaan dengan etos yang juga berubah dari penjajahan menjadi kebangsaan.

Dengan demikian isi kehendak hukum menuntut konsekwensi adanya peruhahan hukum positif yang berlaku sebelumnya, seperti Indische Staatsregeling (is), Algemene Bepalingen van Wetgeving voor Indonesie (AB), Burgellik We(boek (BW), Wetboek van Koophandel (WvK), Wetboek van Straafrecht $(\mathrm{WvS})$ dan segala ketentuan perundang undangan yang dikeluarkan pada masa penjajahan. Peruhahan itu diperlukan dan menjadi bagian penting politik hukum nasional, sebab hukum-hukum yang telah ada ketika proklamasi kemerdekaan telah dipengaruhi dan bercampur baur dengan system hukum atau ideologi yang tidak sesuai dengan Pancasila; padahal pada dasarnya setiap hukum yang berlaku berfungsi sebagai sejarah sosial. Dengan terjadinya perubahan struktur sosial setelah proklamasi kemerdekaan, politik hukum 
harus mengarah pada upaya penyesuaian dengan struktur yang baru sebab hukum bukan bangunan yang statis melainkan bisa berubah karena fungsinya untuk melayani masyarakat.

Meskipun begitu, produk hukum lama yang terpengaruh berbagai sistem dan ideologi tidak mutlak harus seluruhnya diubah, sebab bukan tidak mungkin hukum-hukum peninggalan zaman penjajahan ada yang mengandung nilai universal yang dapat tetap dipakai. Dan dalam BW misalnya, mungkin saja kita dapat menemukan ketentuan yang bersifat universal dan dapat dipertahankan. Oleh karena itu, pembaruan hukurn harus pula diartikan sebagai seleksi terhadap produk hukum yang lama untuk tetap mengambil nilai-nilai yang sesuai dengan idealita dan realita Negara Indonesia atau karena sifatnya yang universal. Masih berlakunva produk hukum peninggalan zaman kolonialisme itu memang ditolerir berdasarkan Pasal 2 dan aturan peralihan UUD 1945 yang menyatakan bahwa hukum yang lama ".masih langsung berlaku selama belum diadakan yang baru..." hal ini dimaksudkan untuk menghindari terjadinya kekosongan hukum, karena hukum-hukum baru yang sesuai dengan idealita dan realita belum sempat dibuat, sehingga pemberlakuan produk hukum lama tak dapat dipandang sebagai politik hukum yang bermaksud melanjutkan kebijaksanaan hukum pemerintah Hindia Belanda. ${ }^{10}$

Politik hukum diartikan sebagai kebijakan dasar penyelengara negara dalam bidang hukum yang akan, sedang dan telah berlaku, yang bersumber dari nilai-nilai yang berlaku dalam masyarakat untuk mencapai tujuan negara yang dicitacitakan. ${ }^{11}$ Moh. Mahfud MD dalam disertasinya, Perkembangan Politik hukum: Studi tentang Pengaruh Konfigurasi Politik terhadap Produk Hukum di Indonesia, menyatakan bahwa karakter suatu produk hukum senantiasa dipengaruhi atau ditentukan oleh konfigurasi politik yang melahirkannya; artinya, konfigurasi politik tertentu dan suatu kelompok dominan (penguasa) selalu melahirkan karakter produk hukum tertentu sesuai dengan visi politiknya. ${ }^{12}$

Marzuki Wahed dan Rumadi juga mengatakan bahwa Teori ini tampaknya didasarkan pada asumsi bahwa hukum merupakan produk politik, atau diberlakukan atas legitimasi politik, sehingga karakter hukurn akan sangat bergantung pada imbangan

\footnotetext{
${ }^{10}$ Mahfud MD, Politik...h 3

11 Imam Syaukani A. Ahsin Thohari, DasarDasar Politik Hukum. (Jakarta: PT Raja Grafindo Persada, 2004), h 58.

${ }^{12}$ Moh. Mahfud MD., "Perkembangan Politik hukum: Studi tentang Pengaruh Konfigurasi Politik terhadap Produk hukum di Indonesiafl, disertasi dalam ilmu hukum pada UGM, (Yogyakirta: tidak diterbitkin, 1993), h 675.
} 
AL-IMARAH: Jurnal Pemerintahan dan Politik Islam Vol. 4, No. 1, 2019

kekuatan politik (konfigurasi politik) yang melahirkannya. $^{13}$

Karakteristik politik hukum satu negara berbeda dengan politik hukum negara yang lain. Perbedaan ini disebabkan karena adanya perbedaan latar belakang kesejarahan, pandangan dunia (world-view), sosio-kultural, dan political will dari masing-masing pemerintah. Dengan kata lain, politik hukum bersifat lokal dan partikular (hanya berlaku dari dan untuk negara tertentu saja), bukan universal. Namun bukan berarti bahwa politik hukum suatu negara mengabaikan realitas dan politik hukum internasional.

Menurut Ichtiyanto, teori eksistensi ialah merumuskan keadaan hukum nasional Indonesia masa lalu, dan masa mendatang bahwa hukum Islam ada dalam hukum nasional Indonesia, baik dalam hukum tertulis maupun tidak tertulis dalam berbagai lapangan kehidupan hukum dan praktek. Teori ini menerangkan tentang adanya hukum Islam di dalam hukum nasional Indonesia itu ialah:

1. Ada dalam arti sebagai bagian integral hukum nasional Indonesia.

2. Ada dalam arti adanya dengan kemandiriannya yang diakui adanya dan kekuatan dan wibawanya oleh hukum nasional dan diberi status sebagai hukum nasional

13 Marzuki Wahed dan Rumadi, Fiqh Madzhab Negara (Yogyakarta, LkiS : 2011), h 4 64
3. Ada dalam hukum nasional dalam arti norma hukum Islam (agama) berfungsi sebagai penyaring bahan-bahan hukum nasional Indonesia

4. Ada dalam arti sebagai bahan utama dan unsur utama hukum nasional Indonesia. ${ }^{14}$

Apakah kemudian salah, atau melanggar Pancasila jika kemudian banyak hukum-hukum Islam yang masuk menjadi hukum nasional? Tentu tidak, sebab hukum agama Islam adalah bagian dari sumber hukum nasional Indonesia. Bahkan bapak Proklamator Ir. Soekarno dalam pidatonya pada tanggal 1 Juni 1945 yang dikutip dan dijelaskan oleh Mahfud MD adalah sebagai berikut: "Untuk pihak Islam, inilah tempat yang terbaik untuk memelihara agama. Kita, sayapun, adalah orang Islam. Maaf beribu-ribu maaf, keislaman saya jauh belum sempurna, tetapi kalau saudara-saudara membuka saya punya dada, dan melihat saya punya hati, tuan-tuan akan dapati tidak lain tidak bukan, hati Islam. Dan hati Islam Bung karno ini, ingin membela Islam dalam mufakat, dalam permusyawaratan". ${ }^{15}$

Menurut Syafi'i Ma'arif, dalam teori politik Sunni, seperti halnya Ibn Taimiyah, institusi pemerintahan adalah simbol tertinggi

${ }^{14}$ Ichtiyanto, "Pengembangan Teori Berlakunya Hukum Islam di Indonesia," dalam Juhaya S.Praja, Hukum Islam di Indonesia Perkembangan dan Pembenmtukan. (Bandung:P.T. Remaja Rosdakarya, 1991), h. 101

15 Mhd Halkis, Konstelasi Politik Indonesia: Pancasila dalam Analisis Fenomenologi Hermeneutika (Jakarta, Yayasan Pustaka Obor Indonesia : 2017), h 249 
syariah. Sebagai seorang politikus Islam, AlMawardi sadar bahwa syariah menjadi pegangan bagi umat Islam. Namun, realitasnya tidak demikian, pada masa Khalifah Abbasiyah menentukan lain. Barangkali inilah yang menjadi salah satu sebab ia menempuh jalan kompromi dalam perumusan teori politiknya sekalipun mengobarnya cita-cita syariah. ${ }^{16}$

Pemberian jabatan kepada orang yang mampu menjalankan tugas di atas pada ummat adalah wajib berdasarkan konsesus ulama. Sekelompok orang berpendapat, bahwa pengangkatan kepala negara hukumnya wajib berdasarkan akal, sebab watak orang-orang berakal mempunyai kecenderungan untuk tunduk kepada kepala negara yang melindungi mereka dari segala bentuk ketidakadilan, memutuskan konflik dan permusuhan yang terjadi di antara mereka. Tanpa kepala negara, manusia berada dalam keadaan chaos, dan menjadi manusia-manusia yang tidak diperhitungkan bangsa-bangsa lain.

\section{Dimensi Kajian Politik Hukum Dan}

\section{Perundang-Undangan}

Setiap kajian tentang hukum tentu akan memiliki dua dimensi, yaitu dimensi filosofis dan dimensi politis. Dua dimensi ini akan selalu kita temukan dan harus dilihat sebagai dua hal yang tidak boleh diabaikan, yaitu :

16 Ahmad Syafi'i Ma'arif, Islam dan Masalah Kenegaraan. (Jakarta: LP3S, 1996), h. 31 a. Dimensi politis dalam kajian hukum melihat adanya keterkaitan yang erat sekali antara hukum dan politik, bahkan ada yang melihat law as a political instrument yang kemudian menjadi lebih berkembang dan melahirkan satu bidang kajian tersendiri yang disebut politik hukum yang kelihatannya dapat mengarah pada perlunya apa yang disebut political gelding van het recht atau dasar berlakunya hukum secara politik, disamping apa yang ada sekarang yaitu landasan yuridis, landasan sosiologis dan landasan filosofis.

b. Dimensi filosofis dalam kajian hukum melihat sisi lain dari hukum sebagai seperangkat ide-ide yang bersifat abstrak dan merupakan penjabaran lebih jauh dari pemikiran filosofis, yaitu apa yang dinamakan filsafat hukum.

Sebab menurut William Zevenbergen mengatakan bahwa politik hukum mencoba menjawab pertanyaan, peraturan-peraturan hukum mana yang patut untuk dijadikan hukum. Perundang-undangan itu sendiri merupakan bentuk dari politik hukum (legal policy). ${ }^{17}$

\section{Objek Kajian Politik Hukum}

Hukum menjadi juga objek poltik, yaitu objek dari politik hukum. Politik hukum berusaha membuat kaidah-kaidah yang akan menentukan bagaimana seharusnya manusia

${ }^{17}$ William Zevenbergen dalam Abdul Latif dan Hasbi Ali, , Politik Hukum, (Jakarta, Sinar Grafika: 2011) h. 19 
AL-IMARAH: Jurnal Pemerintahan dan Politik Islam Vol. 4, No. 1, 2019

bertindak. Politik hukum menyelidiki perubahan-perubahan apa yang harus diadakan dalam hukum yang sekarang berlaku supaya menjadi sesuai dengan kenyataan sosial (sociale werkelijkheid). Akan tetapi, sering juga untuk menjauhkan tata hukum dari kenyataan sosial, yaitu dalam hal politik hukum menjadi alat dalam tangan suatu rulling class yang hendak menjajah tanpa memperhatikan kenyataan sosial itu. $^{18}$

Dalam mengkaji politik hukum maka yang dimaksud adalah keadaan yang berlaku pada waktu sekarang di Indonesia, sesuai dengan asas pertimbangan (hierarki) hukum itu sendiri, atau dengan terminologi Logeman, sebagai hukum yang berlaku di sini dan kini. ${ }^{19}$ Adapun tafsiran klasik politik hukum, merupakan hukum yang dibuat atau ditetapkan negara melalui lembaga negara atas pejabat yang diberi wewenang untuk menetapkannya.

\section{Corak Produk Hukum}

Menurut Moh. Mahfud ada dua karakter produk hukum yaitu : pertama, produk hukum responsif atau populistik adalah produk hukum yang mencerminkan rasa keadilan dan memenuhi harapan masyarakat. Dalam proses pembuatannya memberikan peranan besar dan

18 E. Utrecht, , Pengantar dalam Hukum Indonesia, Cetakan Kesembilan, (Jakarta Penerbitan Universitas : 1966) h:74-75

19 Regen,B.S. Politik Hukum. (Bandung Utomo Press : 2006), h: 17 66 partisipasi penuh kepada kelompok-kelompok sosial atau individu di dalam masyarakat. ${ }^{20}$

Produk politik yang dihasilkan bersifat responsif terhadap tuntutan-tuntutan kelompok sosial atau individu dalam masyarakat. ${ }^{21}$ Dalam arti cirinya selalu melibatkan semua komponen masyarakat (syarat formal) ; Kedua, produk hukum konservatif adalah produk hukum yang isinya (materi muatannya) lebih mencerminkan visi sosial elit politik, lebih mencerminkan keinginan pemerintah, bersifat positivis instrumentalis, yakni masyarakat menjadi alat pelaksanaan ideologi dan program negara. Berlawanan dengan hukum responsif, hukum ortodoks lebih tertutup terhadap tuntutantuntutan kelompok maupun individu-individu di dalam masyarakat. Dalam pembuatannya peranan dan partisipasi masyarakat relatif kecil.

\section{Konfigurasi Politik Hukum}

Untuk mengukur konfigurasi politik dalam setiap produk hukum, apakah demokratis atau otoriter dapat dilihat melalui tiga pilar demokrasi yaitu : peranan partai politik dan Dewan Perwakilan Rakyat; peranan lembaga eksekutif; kebebasan pers (kebebasan memperoleh informasi bagi setiap warga masyarakat). ${ }^{22}$ Berdasarkan tolok ukur tersebut, maka kajian politik hukum perundang-undangan

\footnotetext{
${ }^{20}$ Mahfud MD, Politik... 3

${ }^{21}$ Jazim Hamidi,dkk, , Teori dan Politik Hukum
} Tata Negara. (Yogyakarta, Total Media :2009), h: 232241

${ }^{22}$ Mahfud MD, Politik... h 26 
dapat ditelusuri produk legislatif apakah memenuhi sebagai produk hukum atau produk politik.

Dengan demikian,tujuan politik hukum, pada dasarnya adalah produk hukumyang dilahirkan oleh para politikus untuk mengatur bangsa sesuai dengan kondisi dan keadaan yang ada pada saat tertentu. Tujuannya adalah demi kemaslahatan dan kebaikan bersama demi terciptanya berkehidupan dan berkebangsaan yang aman dan damai sentosa.

\section{B. Terminologi Politik Hukum Islam}

\section{Definisi Politik Hukum Islam}

Dalam term politik Islam, Politik itu identik dengan siyasah, yang secara kebahasaan artinya mengatur. Kata ini diambil dari akar kata "sasa-yasusu-siyasatan",yang berarti mengemudikan, mengendalikan mengatur dan sebagainya. Al Qaradhawy dalam bukunya Al Siyasah al-Sya'iyyah menyebutkan dua bentuk makna siyasah menurut ulama, yaitu arti umum dan arti khusus. Secara umum siyasah berarti pengaturan berbagai urusan manusia dengan syari'at agama Islam. Secara khusus siyasah bermakna Kebijakan dan aturan yang dikeluarkan oleh penguasa guna mengatasi suatu mafsadat yang timbul atau sebagai solusi bagi suatu keadaan tertentu. Sementara Ahmad Fathi Bahansi mendefinisikan Siyasah Syar'iyyah dengan pengertian sederhana, yaitu pengaturan kemaslahatan manusia berdasarkan syara'. 23

Berikut ini adalah beberapa definisi secara terminologi tentang siyasah syar'iyyah (hukum politik Islam) menurut berbagai ahli ${ }^{24}$ :

a. Menurut Ibnu Nujaim, siyasah syariyyah adalah: "Suatu tindakan atau kebijakan yang dilakukan seorang penguasa demi kemaslahatan yang dipandangnya baik, meskipun belum ada dalil/argumentasi yang terperinci yang mengaturnya."

b. Menurut Ibnu Aqil al Hanbali, siyasah syariyyah adalah: "Suatu tindakan atau kebijakan yang membawa umat manusia lebih dekat kepada kemaslahatan dan menjauhkan mereka dari kerusakan, meskipun tidak ada hadis yang mengaturnya atau wahyu yang turun (terkait hal itu)."

c. Menurut Abdurrahman Taj, siyasah syariyyah adalah: "Suatu nama bagi kumpulan aturan dan prilaku dalam mengatur urusan ketatanegaraan Islam di bidang pemerintahan, perundang-undangan, peradilan, dan semua kekuasaan eksekutif, administratif, serta aturan hubungan luar negeri yang terkait dengan bangsa-bangs lain."

${ }^{23}$ Ahmad Fathi Bahansi, Al Siyasah al Jinayah fi al Syari'ah al Islamiyah, (Beirut, Dar al Arubah : 2001), h 61

24 Akram Kassab, Al Siyasah al Syar'iyyah, Mabadi' wa Mafahim, Dhawabith wa Mashadir, Makalah Jurnal Online International Union for Muslem Scholars (IUMS) dari website http://iumsonline.org/ar/2/b9/ diakses pada tanggal 12 November 2018. 
d. Menurut Abdul wahab Khallaf, siyasah syariyyah adalah: "Suatu ilmu yang membahas tentang urusan ketatanegaraan Islam dari sisi aturan perundang-undangan dan sistim yang sesuai dengan prinsip-prinsip Islam, meskipun tidak ada dalil khusus mengenai hal itu."

e. Menurut Yusuf Al Qaradhawi, siyasah syariyyah adalah: "Politik yang bersendikan kaedah-kaedah, aturan dan bimbingan syara'.

f. Menurut Abdul 'Al 'Atwah, siyasah syariyyah adalah: "Kumpulan hukum dan sistem dalam mengatur urusan umat Islam dengan mempertimbangkan kesesuaiannya dengan ruh syari'at, menjalankannya berdasarkan kaedah-kaedah yang umum, serta merealisasikannya sesuai dengan tujuan masyarakat."

g. Menurut Sa'ad bin Mathar al 'Utaibi, siyasah syariyyah adalah: "Setiap kebijakan apa saja yang ditetapkan oleh para pemimpin (ulil amri), berupa aturan-aturan serta teknis prosedur pelaksanaan yang terkait dengan kemaslahatan, meski tidak ada dalil syara' yang khusus terkait hal itu, selama tidak bertentangan dengan syari'at.

h. Menurut Ibu Aqil

$$
\text { تدبير مصالح العباد على وفق الثرع }
$$

"Pengaturan terhadap kemaslahatan bangsa sesuai dengan aturan syara'
السياسة ما كان فعلا يكون معه الناس أقرب إلى الصلاح

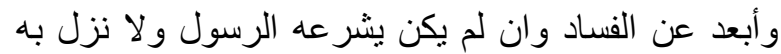

"Siyasah adalah suatu perbuatan yang membawa manusia dekat kepada kemaslahatan dan terhindar dari kerusakan walaupun Rasul tidak menetapkanya dan Allah tidak mewahyukannya". Pada prinsipnya semua ahli hukum islam mempunyai persepsi dan definisi yang hampir sama tentang siyasah dusturiyyah/syar'iyyah/fiqh siyasah. Taqiyuddin an-Nabhani menambahkan bahwa landasan seluruh peraturan negara, baik undang-undang maupun peraturan perundang-undangan harus digali dari AlQur'an dan Sunnah. Dengan kata lain, seluruh bentuk peraturan negara ditentukan berdasarkan hukum-hukum syara' yang digali dari akidah Islam dengan menempatkan ijma dan qiyas sebagai pendukung. ${ }^{25}$ Sedangkan Hukum Islam adalah suatu sistem hukum di dunia yang sumber utamanaya adalah wahyu Allah, sehingga mempunyai konskuensi atau pertanggungjawaban di akhirat kelak. Untuk itu hukum Islam dapat berupa hukum yang secara langsung berasal dari wahyu (syari'ah) atau hukum yang merupakan hasil

${ }^{25}$ Taqiyuddin al-Nabhani, Sistem Pemerintahan Islam; Doktrin, Sejarah dan Realitas Empirik, Cet. I (Bangil; Al-Izzah, 1996) h 17 
ijtihad para mujtahidin (fiqh), yang kedua inilah yang lebih banyak.Menurut Kamsi, dalam artikelnya yang berjudul 'Politik Hukum Islam pada masa Orde Baru', yang mengutip dari tulisan Ichtiyanto, "Pengembangan Teori Berlakunya Hukum Islam di Indonesia,” dalam Juhaya S. Praja, "Hukum Islam di Indonesia Perkembangan dan Pembentukan”, beliau mengatakan bahwa yang dimaksud dengan Politik Hukum Islam adalah upaya kebijakan pemberlakuan hukum Islam sebagai salah satu hukum yang hidup dalam masyarakat, yaitu dengan memperhatikan tentang segi KEBHINNEKAAN (Pluralitas), dan dalam proses pemberlakuan harus memperhatikan pula atau berorientasi kepada kepentingan bangsa atau nasional (Integritas), artinya terlayaninya segala segi kehidupan tanpa menimbulkan goncangan dan keresahan, tanpa paksaan, dan tetap menghormati nilainilai esensial yang mengandung sifat keragaman. Maka hukum yang mengabdi kepentingan ini tidak harus berujud satu unifikasi hukum, tetapi berujud satu kodifikasi hukum yang mengandung unifikasi hukum, dalam bidang hukum tertentu (yang netral dari keyakinan agama) dan mengandung diferensiasi hukum dalam bidang hukum yang sangat akrab dengan dengan keyakinan agama (hukum Islam). ${ }^{26}$

\section{Ciri-ciri Politik Hukum Islam}

Dari berbagai definisi tentang siyasah dapat disimpulkan bahwa hukum politik Islam memiliki ciri-ciri sebagai berikut:

1) Berorientasi kemaslahat individu dan umat

2) Berlandaskan ideologi agama

3) Memiliki aspek tanggungjawab akhirat

4) Adanya seni dan kreasi penguasa dalam pengaturan pemerintahan maupun perundang-undangan meski tidak diatur secara eksplisit dalam Alquran dan Hadis

5) Siyasah yang diinginkan adalah yang bersumber dari syariat agama dan bukan politik atas dasar kepentingan, kedzaliman maupun kecurangan.

\section{Objek kajian Politik Hukum Islam}

Objek kajian Politik Islam tentu searah dengan tujuan syariat Islam yang diturunkan di muka bumi ini. Oleh sebab itu,ada beberapa pendapat pakar politik hukum Islam yang menjelaskan objek kajian politik Islam sebagai berikut :

a. Menurut Abdul Wahab Khallaf; objek kajian fiqh siyasah adalah pengaturan dan perundang-undangan yang dibutuhkan untuk

${ }^{26}$ Kamsi, Politik Hukum Islam pada masa Orde Baru. Diunduh pada tanggal 10-11-2018 pada jam 10 pagi. Lihat juga di Ichtiyanto, "Pengembangan Teori Berlakunya Hukum Islam di Indonesia," dalam Juhaya S.Praja, Hukum Islam di Indonesia Perkembangan dan Pembenmtukan. (Bandung:P.T. Remaja Rosdakarya, 1991), h. 97. 
mengurus negara sesuai dengan pokok-pokok ajaran agama dengan tujuan mewujudkan kemaslahatan manusia serta memenuhi kebutuhan mereka.

b. Menurut Hasbi Ashshiddiqie; objek kajian fiqh siyasah adalah pekerjaan-pekerjaan mukallaf dan urusan-urusan mereka dari jurusan pentadbirannya, dengan mengingat persesuaian pentadbiran itu dengan jiwa syaril'ah, yang kita tidak peroleh dalilnya yang khusus dan tidak berlawanan dengan sesuatu nash dari nash-nash yang merupakan syaril'ah l'ammah yang tetap.

Objek fiqh politik menjadi luas, sesuai kapasitas bidang-bidang apa saja yang perlu diatur, seperti peraturan hubungan warga negara dengan lembaga negara, hubungan dengan negara lain, Islam dengan non Islam ataupun pengatuaran-pengaturan lain yang dianggap penting oleh sebuah negara, sesuai dengan ruang lingkup serta kebutuhan negara tersebut.

\section{Maqashid Al-Syariah}

\section{Secara Etimologis}

Kalimat Maqashid al-Syariah terbentuk dari dua kalimat, yakni maqashid dan Syari'ah. Maqashid berarti kesengajaan atau tujuan, Maqashid merupakan bentuk jama' dari maqsud yang berasal dari suku kata Qashada-yaqshiduqasdan- maqshadan

$$
\text { (فَصَنَ - يَقْهِدُ - قَصنداً - و مَقْصَدا ) diambil }
$$

dari masdar mim-nya yang berarti menghendaki atau memaksudkan, Maqashid berarti hal-hal 70 yang dikehendaki dan dimaksudkan. ${ }^{27}$ Maqashid bentuk plural dari kata maqshod yang merupakan devariasi dari kata fi'il di atas. Maqashid memiliki varian makna yang beragam, seperti tujuan,

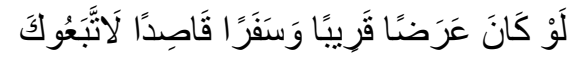

Kalau yang kamu serukan kepada mereka itu keuntungan yang mudah diperoleh dan perjalanan yang tidak seberapa jauh, pastilah mereka mengikutimu

Bermakna tengah-tengah;

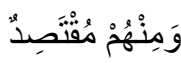

dan di antara mereka ada yang pertengahan.

Maqashid bermakna lurus.

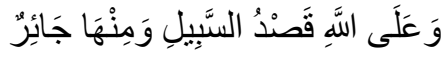

Dan hak bagi Allah (menerangkan) jalan yang lurus, dan di antara jalan-jalan ada yang bengkok suatu arah, jalan lurus, tidak melampui batas. $^{28}$

Sedangkan kata syariah, secara etimologi kata Syariah memiliki arti sebagai "jalan"e sesuai dengan makna yang berasal dari ayat al-Qur'an:

"Kemudian kami jadikan kamu berada di atas suatu syariat (peraturan) dari urusan (agama itu), Maka ikutilah syariat itu dan janganlah kamu ikuti hawa nafsu orang-orang yang tidak Mengetahui".

27 Ibn 'Ashur, Maqasid al-Shari'ah alIslamiyyah, h, 350. Jasser Auda, Maqasid al-Shari 'ah as Philosophy of Islamic Law, h, 5

28 Al-Fayumi, Al-Misbahul Munir li Gharibi syarhil kabir li ar-rafi'i. (Beirut : Maktabah Lubnan, 1987), h 192 
Di dalam Lisanul Arab, kata syariah bermakna :

$$
\text { مورد الماء يقصد للشرب }
$$

Sumber mata air yang dijadikan tempat untuk minum. ${ }^{29}$ (Lisanul Arab pada kata jilid 8 hal. 179). Makna mauridu ash-sharibah sebagaimana perkataan orang arab ( شرعت (الإبل 'Unta yang keluar menuju sumber air untuk diminum'. Sedang menurut Amir Sarifuddin, kata Syara' berasal dari kata syara'a - yasyra'u - syar'an ( شرع - يشرع - شرعا ) yang secara etimologi berarti jalan, yaitu jalan yang dapat ditempuh air, maksudnya adalah jalan yang dilalui manusia untuk menuju Allah. Apabila kata hukum dirangkai dengan kata syara' yaitu Hukum Syara' berarti seperangkat peraturan berdasarkan ketentuan Allah SWT. Tentang tingkah laku manusia yang diakui dan diyakini berlaku serta mengikat untuk semua umat yang beragama Islam ( Amir Syarifuddin I, 1997 : 281 ).

Syari'ah terkadang secara bahasa berarti

$$
\text { المو اضع تحدر الي الماء }
$$

artinya Jalan menuju sumber air, jalan menuju sumber air dapat juga diartikan berjalan menuju sumber kehidupan

Ada sebagian orang-orang Arab di masa lalu memaknai kata syariah ini sebagai metode atau jalan yang lurus (الطريقة المستقيمة) (Manna' Al-Qaththan, 2002, hal, 14). Kata shariah yang

29 Fazlur Rahman, Islam, alih bahasa: Ahsin Muhammad, ( Bandung: Pustaka, 1994), h. 140. bermakna 'jalan lurus' sesuai dengan Firman Allah SWT :

Dia telah mensyari'atkan bagi kamu tentang agama apa yang telah diwasiatkan-Nya kepada Nuh dan apa yang telah Kami wahyukan kepadamu dan apa yang telah Kami wasiatkan kepada Ibrahim, Musa dan Isa Yaitu: Tegakkanlah agama[1340]7 dan janganlah kamu berpecah belah tentangnya. (Q:S, 42: 13)

Dari pemakanaan ayat diatas bisa disimpulkan bahwa Syariat sama dengan Agama, namun dalam perkembangannya telah terjadi reduksi muatan arti Syari'at. Aqidah misalnya, tidak masuk dalam pengertian Syariat, Syeh Muhammad Syaltout misalnya sebagaimana yang dikutip oleh Asafri Jaya Bakri dalam bukunya Konsep Maqashid Syari'ah menurut al-Syatibi mengatakan bahwa Syari'at adalah: Aturan-aturan yang diciptakan oleh Allah SWT untuk dipedomani oleh manusia dalam mengatur hubungan dengan tuhan, dengan manusia baik sesama Muslim maupun non Muslim, alam dan seluruh kehidupan. $^{30}$

\section{Secara Terminologis}

Abu Ishaq Al-Syatibi mendefiniskan: "maqashid syari'ah bertujuan mewujudkan kemaslahatan manusia di dunia dan akhirat." berarti tujuan dan fungsi syariat

30 Asafri Jaya, Konsep Maqashid, h. 62.bisa dilihat: Mahmud Syaltout, Islam: 'Aqidah wa Syari'ah, (Kairo: Dar al-Qalam,1966), h. 12. 
AL-IMARAH: Jurnal Pemerintahan dan Politik Islam Vol. 4, No. 1, 2019

berupa mendatangkan kemaslahatan, baik dalam bentuk mewujudkan maupun memelihara kemaslahatan tersebut serta menghilangkan dan meolak segala bentuk kerusakan. Syatibi sendiri tidak mengambil perhatian utuk mendefinisikan Maqashid dalam bentuk jami' mani' dan terbatas, akan tetapi, ia hanya memperkenalkan Maqashid lewat penjabaran teori-teorinya yang meluas. Adapun ulama yang berusaha meletakkkan definisi dan membatasi makna maqashid adalah Imam Ibnu Asyur. Dikatakan "Maqashid tasyri' secara umum adalah, beberapa makna dan hukum yang diinginkan oleh Tuhan pada segala kondisi tasyri', dimana keinginan tersebut tidak hanya terbatas pada satu macam hukum syariat, akan tetapi semua bentuk hukum syariah yang tujuan dan maknaya termasuk di dalamnya. Juga termasuk maknamakna hukum yang tidak terekam dalam berbagai macam hukum, akan tetapi terekam dalam bentuk-bentuk yang lain. ${ }^{31}$

Dari penjelasan diatas memang tidak ada satu ketegasan tentang definisi Maqashid Syari'ah namun demikian ada sebagian Ulama mendefinisikan Maqashid Syariah sebagai mana penulis kutip ketika kuliah bersama Prof. Dr. Nawir Yuslim, M.A yaitu:

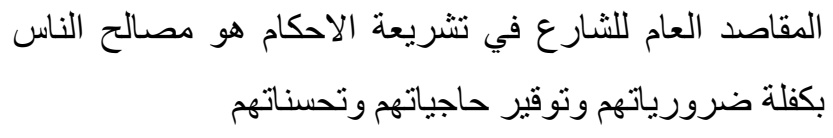

${ }^{31}$ Makalah Mulawarman Hannas yang berjudul Epistimologi Maqashid Asy-Syariah Versi Syathiby yang mengutip dari karangan Thahir ibnu Asyur, Maqashid assyariyah al-Islamiyah, h. 51 72
"Maqashid Syari'ah secara Umum adalah: kemaslahatan bagi Manusia dengan memelihara kebutuhan dharuriat mereka dan menyempurnakan kebutuhan Hajiat dan Tahsiniat mereka"32

Definisi yang dianggap bisa mewakili makna terdekat Maqasid syariah, bisa dikatakan seperti yang termaktub dalam kitabnya AsySyathiby "Maqashid adalah, segala sesuatu yang dimaksudkan oleh Shahibus as-Syari' (Allah) pada semua kondisi tasyri' atau penetapan hukum yang berlaku. Lebih lanjut al-Syatibi menyatakan:

هذه الثريعة وضعت لتحقيق مقاصد الثارع في قيام مصالحهم

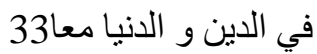

Eksistensi Syariat diletakkan/ditentukan untuk mewujudkan tujuan-tujuan Syari' dalam menggapai kemaslahatan manusia di dunia dan di akhirat.

Dari pengertian tersebut, dapat dikatakan bahwa tujuan syariah menurut Imam al Syatibi adalah kemaslahatan umat manusia. Berkaitan dengan hal tersebut, ia menyatakan bahwa tidak satu pun hukum Allah SWT yang tidak mempunyai tujuan karena hukum yang tidak

${ }^{32}$ Disadur pada jam 21. Tanggal 30-09-2017 dari Tulisan Bapak Abdullah yang di publikasikan di Kompasiana.com beliau mendengar langsung dari dosennya bapak Prof, Dr. Nawir Yuslim, M.A, yang mendefinisikan maqashid asy-syariah dalam mata kuliah Usul fiqih Perbandingan, pada semester 2, HUKI di kampus, IAIN, SU, pada tanggal 17-7-2009.

33 Asy-Syatibi, al-Muwafaqat fi Ushul alSyari'ah, (Kairo: Musthafa Muhammad, t.th), Jilid 2, h. 374. 
mempunyai tujuan sama dengan membebankan sesuatu yang tidak dapat dilaksanakan. Kemaslahatan, dalam hal ini diartikannya sebagai segala sesuatu yang menyangkut rezeki manusia, pemenuhan penghidupan manusia, dan perolehan apa-apa yang dituntut oleh kualitaskualitas emosional dan intelektualnya, dalam pengertian yang mutlak. ${ }^{34}$

Dari beberapa penjelasan di atas, setiap hukum yang ditetapkan terhadap manusia pasti memiliki tujuan-tujuan tertentu yang biasa disebut dengan Maqashid asy-Syari'ah " مقاصد "الثريعة". Dengan tujuan-tujuan ini, manusia dapat mempertimbangkan setiap kondisi dan situasi dalam memilih sebuah pilihan (ijtihad) akan suatu masalah yang dihadapinya jangan mengikuti hawa nafsu. Teori Maqashid syariah tiada lain merupakan metode untuk mengetahui tujuan syari' (Allah) dalam memberikan justifikasi hukum terhadap permasalahan manusia secara universal untuk mendatangkan kemaslahatan dan menolak kemudharatan. Abu Zahra' menjelaskan dalam kitabnya bahwa setiap hukum Islam memiliki tujuan yang hakiki, yaitu kemaslahatan. Tidak ada perintah dalam Al-Qur'an dan Sunnah yang tidak memiliki kemaslahatan yang hakiki, meskipun kemaslahatan itu tidak tampak dengan jelas. Kemaslahatan di sini adalah kemaslahatan nyata

34 Asy-Syatibi, al-Muwafaqat fi Ushul alSyari'ah, (Kairo: Musthafa Muhammad, t.th), Jilid 2, h. 374. yang bersifat umum atau khusus dan tidak didasarkan pada pemenuhan hawa nafsu belaka. $^{35}$

Secara umum tujuan hukum Islam adalah kebahagiaan hidup manusia di dunia dan di akhirat, dengan jalan mengambil semua manfaat dan menolak atau mencegah segala mudarat, yaitu yang tidak berguna bagi hidup dan kehidupan apakah itu bersumber dari perintah atau larangan, atau bersifat umum atau khusus. $^{36}$

Imam al-Syathibi sebagai seorang imam yang dianggap sebagai peletak pertama tentang term khusus maqashid syari'ah, beliau mengembangkan doktrin maqashidus Syari'ah dengan menjelaskan bahwa tujuan akhir hukum Islam adalah satu, tidak ada yang lain yaitu kemaslahatan, kedamaian, kebaikan dan kesejahteraan umat manusia dunia dan akhirat. Pendapat al-Syathibi didasarkan pada prinsip bahwa Allah SWT (sebagai Shahibuus Syari'/pembuat syariat) melembagakan syari'ah (hukum Islam) demi kemaslahatan manusia, baik jangka pendek maupun jangka panjang. Al-Syatibi menjelaskan bahwa tujuan hukum Islam tersebut setelah melakukan penelitian mendalam terhadap ayat-ayat dalam Al-Qur'an

35 Muhammad Abu Zahrah, Ushul al-Fiqh (Beirut: Dar al-Tsaqafah, Tt.), h. 366

${ }^{36}$ Mustafa, Hukum Islam Kontemporer (Jakarta: Sinar Grafika, 2009), h. 6 
AL-IMARAH: Jurnal Pemerintahan dan Politik Islam Vol. 4, No. 1, 2019

dapat disimpulkan tujuannya adalah untuk maslahah dan ramat bagi manusia. ${ }^{37}$

\section{Faedah danTujuan pokok mempelajari}

\section{Maqashid Syari'ah}

Ulama berbedada pendapat tentang faedah dan tujuan mempelajari ilmu maqashid syariah, ada yang mengatakan kalau faedah itu berarti sesuatu yang dihasilkan setelah melakukan pekerjaan, biasa dikatakan sebagai hasil atau buah, sedang tujuan adalah sesuatu yang yang dihasilkan ketika mulai berfikir, sesuatu yang muncul saat hendak melakukan pekerjaan. Sebagian ulama lagi tidak membedakan antara faedah dan tujuan karena keduanya bemakna satu. Yaitu sesuatu yang dihasilkan dari setelah melakukan sesuatu.

Adapun faedah dan tujuan maqashid syari'ah antara lain :

a. Penetapan qawaid yang nantinya akan membantu mujtahid dalam menggali hukumhukum syariat dan mengetahui kemaslahatan yang menjadi tujuan syari' yang dibebankan kepada mukallaf dengan hukum-hukum tadi

b. Kemampuan mujtahid dalam menggali hukum setelah mengetahui qawaid dan maqashid dan membantu mempermudah mujtahid untuk sampai pada kemaslahatan terhadap hasil hukum yang telah digali sebagaimana tujuan Syari'

\footnotetext{
${ }^{37}$ Abu Ishaq Al-Syatibi, Al-Muawafaqat Fi 'Ilmi al-Usul (Kairo: Dar al-Hadits. Juz II) h. 262 74
}

c. Setelah mengetahui qawaid dan maqashid, mampu mewujudkan hubungan perkara baru dengan perkara dahulu sehingga bisa menetapkan hukum syar'i yang sesuai.

d. Mampu membedakan pendapat-pendapat yang berbeda-beda dan mengambil pendapat yang paling unggul.

e. Mengetahui Mqashid syari'ah akan menjadikan mujtahid menguasai terhadap hukum-hukum syara', memahami kulliyat syari'a dan ini sangat bermanfaat dalam pengetahuannya dalam hal juz'iyyat menetapkan hukum tertentu.

f. Rasa yakin bagi seorang yang alim dengan qawaid dan maqashid terhadap hukumhukum yang diambil dari kitab-kitab klasik sehingga tampak terang benderang bahwa hukum yang diambil/ditetapkan sesuai dengan qaidah-qaidah dan maqashid yang kuat dan mantap.

g. Bagi seorang mujtahid mampu menolak orang-orang yang menolak qiyas dengan menggunakan qawaid dan maqashid

h. Pengetahuan tentang maqashid akan membantu dalam membahas qiyas dan memperaktekkannya dalam masalah-maslah baru yang akan terjadi.

i. Pengetahuan tentang maqashid akan memberi manfaat pada saat berhadapan dengan teks syar'i yang bertentangan dengan maqashid, karena pengetahuan ini akan memberi seorang mujtahid keyakinan yang 
lebih bahwa nash/teks yang saling bertentangan perlu pembasahan yang mendalam sehingga tampaklah mana pada hakikatnya teks/nash tadi tidak saling bertentangan.

j. Kemampuan seorang mujtahid/'alim dengan memamahi qaidah-qaidah(qawaid) dan maqashid untuk untuk mendalami agama Islam yang terkumpul di dalamnya qaidahqaidah dan maqashid yang sejatinya bagus bagi setiap wakatu dan tempat sehingga qaidah tadi mampu mewujudkan hukumhukum baru dari kejadian-kejadian baru dimanapun dan kapanpun tanpa memandang tempat dan waktu (space and time).

k. Pengetahuan tentang maqashid syari' akan memberi faedah dalam pengetahun bahwa agama sejatinya menjaga keadaan mukallaf dalam melaksanakan hukum-hukum yang dibebankan kepadanya ${ }^{38}$

\section{Urgensi Mempelajari Maqashid Syariah}

Ilmu Maqashid Syariah yang ada semenjak risalah Islam turun di Makkah bahkan ada sebelum Rasul SAW diutus pada NabiNabi sebelumnya hingga sampai sekarang terkadang layu dan lemah, terkadang muncul dan bahkan kadang menjadi kuat untuk dibahasnya. Para ulama-ulama klasik telah menulis dalam buku-buku mereka mereka tahu tentang pentingnya belajar ilmu Maqashid

${ }^{38}$ Abdul Aziz bin Abdurrahman, Ilmu Maqashid Syari'ah, (Riyadh : Maktabah Malik Fahd, 2002), hln 38
Syariah hanya saja mereka belum sempat menulisnya. Sehingga perlu ditulis tentang pentingnya mempelajari Maqashid Syariah agar mereka tahu bahwa hukum dan syariat yang diturunkan melalui Rasul SAW sama seklai tidak memberatkan bagi umatnya, karena sejatinya berdiri tegak hukum tersebut untuk menghilangkan kesukan, keribetan dan tidak dibebankan kepada orang yang tidak mamppu melaksanakannya. Beberapa manfaat mempelajari ilmu Maqashid Syariah diantaranya adalah :

a. Maqashid Syariah akan membantu dalam masalah yang bertentangan atau yang pendapat satu lebih unggul dari salah satu pendapat lainnya.

b. Maqashid Syariah akan membantu memahami sebagian hukum-hukum syara'.

c. Maqashid Syariah akan membantu di dalam memahami nash-nash dan tujuannya.

d. Maqashid Syariah akan membantu dalam mengarahkan fatwa.

e. Kebutuhan terhadap pengetahuan Maqashid Syariah dalam memutuskan illat suatu hukum syariah untuk dijadikan landasan dalam menentukan hukum qiyas.

f. Keputusan atau ketetapan Maqashid Syariah dalam mengambil pendapat-pendapat para sahabat dan salafus shalih dari kalanga ahli fiqh dan mengetahi dalil-dalilnya. 
AL-IMARAH: Jurnal Pemerintahan dan Politik Islam Vol. 4, No. 1, 2019

g. Butuh pada ilmu Maqashid Syariah dalam ilmu praktis untuk menentukan hukum yang menggunakan dalil hadits ahad.

h. Memutuskan suatu hukum kekinian (kontempporer) selama belum ada dalil dan belum ada perbandingan dalam qiyas terhadapnya. Ini manfaat yang paling penting dalam Maqashid Syariah al-islamiyah secara umum. $^{39}$

\section{Metode Penetapan Maqasid}

Imam Syathibi setidaknya merumuskan bahwa penetapan adanya maqashid syari'ah dalam suatu hukum yang telah ditetapkan dapat ditempuh melalui empat metode berikut ini :

1. Mujarrad al amr wa an nahy al ibtida'i at tasrihi

Secara sederhana, metode ini dapat dipahami sebagai sebuah upaya melihat ungkapan eksplisit perintah dan larangan dalam nash, yang eksistensi kedua unsur tersebut ada secara mandiri (ibtidai). Sebagaimana dipahami, suatu perintah menuntut ditunaikannya perbuatan yang diperintahkan, sementara suatu larangan menuntut dijauhinya perkara yang dilarang. Maka terwujudnya perbuatan yang dikehendaki perintah syari'at, atau tercegahnya perkara yang dilarang, dapat disimpulkan berkesesuaian dengan kehendak Allah SWT (maqshud asy syari'). Bila yang terjadi adalah

39 Samih Abdul Wahab al-Jundi, Ahammiyatul Maqashid fi Syari'ah al-Islamiyah, Beirut: Ar-Risalah, 2008, h 97-98 hal yang sebaliknya, perkara yang diperintahkan tidak terlaksana, atau perkara yang dilarang justru tetap dilaksanakan juga, maka hal itu dianggap menyelisihi maqshud asy syari' ${ }^{40}$

Dengan demikian, penetapan dengan cara ini bisa dikategorikan sebagai penetapan berdasarkan literal nash, yang dibingkai dengan pemahaman umum bahwa dalam perintah syari'at pasti terdapat unsur maslahat dan dalam setiap larangan pasti ada unsur mafsadat.

Sekalipun demikian, bila menilik redaksi yang diungkap oleh Imam Syatibi, terindikasi dua syarat operasional yang dikemukakan, yaitu: Pertama, Perintah dan larangan itu diungkapkan secara eksplisit dan mandiri (ibtidai) Berdasarkan syarat ini, maka perintah yang sifatnya penguat saja tidak bisa digunakan dalam metode ini. Misalnya, larangan jual beli dalam firman Allah SWT dalam surat al Jum'ah ayat 9:

Yang bukan merupakan larangan jual beli secara murni dan mandiri (ibtida'i), melainkan sebatas larangan untuk menguatkan perintah as sa'yu ila adz dzikr (bersegera untuk melaksanakan shalat jum'at).

Kedua, perintah dan larangan itu harus diungkapkan secara eksplisit (sarih) Dengan adanya syarat ini, maka perintah dan larangan yang bersifat dhimni, atau yang dipahami dari mafhum an nushush (seperti mafhum muwafaqah dan mukhalafah, dll), maupun yang dipahami dari kaidah-kaidah fiqih (seperti ma la

${ }^{40}$ Syatiby, ibid h 393 
yatimm al wajib illa bihi fa huwa wajib, atau alarm bi asy syai' nahyun an dhiddih, dll), tidak bisa digunakan untuk menetapkan maqashid al syari'ah berdasarkan pendekatan ini.

2. Memperhatikan konteks illat dari setiap perintah dan larangan

Metode ini pada hakikatnya masih memiliki keterkaitan erat dengan metode pertama, tetapi titik fokusnya lebih pada pelacakan illat di balik perintah dan larangan. Pada tataran ini, penetapan maqashid berangkat dari pertanyaan-pertanyaan mendasar tentang ada apa di balik perintah dan larangan itu? Mengapa perkara ini diperintahkan? Mengapa hal itu dilarang? Dengan pembahasan ini, al Syatibi tidak menjadikan illat sebagai maqashid itu sendiri, melainkan sebatas alamat atau isyarat yang mengarahkan kepada maqashid. Adapun yang dijadikan maqashid adalah konsekwensi ideal dari illat (muqtadha al ilal) dari sisi terlaksananya perbuatan yang diperintahkan dan tercegahnya perkara yang dilarang .

Illat dibedakan menjadi dua, yaitu illat yang diketahui (ma'lumah) dan illat yang tidak diketahui (ghairu ma'lumah). Illat ma'lumah, wajib untuk diikuti oleh seorang mujtahid dalam proses ijtihadnya, berdasarkan kaidah-kaidah masalik al illat yang banyak dibahas dalam ilmu ushul fiqh. Adapun illat ghairu ma'lumah, sikap yang wajib diambil adalah tawaqquf, serta tidak secara gegabah dan spekulatif memutlakkan klaim bahwa yang dikehendaki Allah SWT adalah begini dan begitu.

Sebab dipilihnya sikap tawaqquf terhadap illat ghairu ma'lumah karena dua hal, yaitu: Pertama, tawaqquf karena ketiadaan dalil yang menunjukkan illat dalam nash. Kedua, tawaqquf karena sekalipun ada illat yang manshush, tetapi bisa jadi bukan merupakan maqshud asy syari'.

3. Memperhatikan semua maqashid turunan (at tabi'ah)

Semua ketetapan syari'at, ibadah maupun mu'amalah, memiliki tujuan yang bersifat pokok (maqshud al ashli) dan yang bersifat turunan (maqashid at tabi'ah). Dalam syari'at nikah misalnya, yang menjadi maqshud al ashli adalah kelestarian manusia lewat perkembang-biakan (at tanasul). Sementara setelahnya, terdapat beberapa maqashid turunan (tabi'ah) seperti mendapatkan ketenangan (as sakinah), tolong-menolong dalam kemaslahatan duniawi dan ukhrawi, penyaluran hasrat biologis manusiawi (al istimta') secara halal, membentengi diri dari terpaan fitnah, dll, semua itu merupakan akumulasi dari maqashid at tabi'ah dalam syari'at nikah.

Dari semua maqashid itu, ada yang diungkapkan secara eksplisit oleh nash (manshush), ada yang sebatas isyarat yang mengindikasikan kepada maqashid, dan ada pula yang dipahami dari dalil-dalil lain atau disimpulkan berdasarkan penelusuran secara 
AL-IMARAH: Jurnal Pemerintahan dan Politik Islam Vol. 4, No. 1, 2019

induktif (maslak al istiqra') dari nash-nash yang ada. Maka keberadaan semua maqashid yang bersifat turunan ini dianggap sebagai kehendak Allah (maqshud asy syari') yang berfungsi untuk menguatkan dan menetapkan eksistensi maqshud al ashli. Bahkan lebih jauh, semua maslahat yang muncul secara empirik dari syari'at nikah sekalipun tidak manshush, diposisikan sebagai penguat terhadap maqshud ashli. Dengan demikian, semua hal yang bertentangan terhadap semua maqashid baik ashli maupun tabi'ah, baik maslahat yang manshush maupun maslahat yang empirik, dianggap menyelisihi maqshud asy syari'.

\section{Tidak adanya keterangan syar'i (sukut asy} sayri')

Maksud dalam bahasan ini adalah tidak adanya keterangan nash mengenai sebab hukum atau disyari'atkannya suatu perkara, baik yang memiliki dimensi ubudiyah maupun mu'amalah, padahal terdapat indikasi yang memungkinkan terjadinya perkara tersebut pada tataran empirik. Secara rinci, cakupan perkara yang tidak ada keterangan syar'i ini dipetakan pada dua jenis

Pertama, Ketiadaan keterangan karena belum adanya kebutuhan tasyri' untuk menjelaskannya.

Persoalan yang masuk dalam kategori ini adalah semua persoalan baru yang muncul (an nazilah) setelah wafatnya Rasulullah. Karena pada hakikatnya, hal itu belum eksis pada masa tasyri' ketika Rasulullah SAW masih hidup 78 (seperti kodifikasi al Quran, pembukuan ilmu pengetahuan, dll). Terkait dengan hal ini, upaya mengetahui dan menetapkan maqashid-nya adalah dengan mengembalikan furu' kepada ushul yang relevan, atau dengan menelusuri nash-nash yang memiliki keterkaitan dan menyimpulkannya secara induktif atau al istiqra. $^{41}$

Kedua, Perkara yang telah berkemungkinan ada di masa tasyri', tetapi tidak ada keterangan syari'at terhadapnya.

\section{Hukum Mempelajari Maqashid Syari'ah}

Ulama berbeda pendapat dalam hokum mempelajari Maqashid syari'ah, perbedaan lebih lebih disebabkan oleh tingkatan manusia dari segi kualitas mereka. Bagi mereka yang ingin melakukan ijtihad, atau ingin mengeluarkan fatwa, dan memutuskan suatu perkara hokum diantara manusia, maka belajar tentang ilmu Maqashid syariah fardhu 'ain baginya, ini disebabkan karena wajib baginya untuk menegakkan hokum Allah terhadap makhluk-Nya dan menjelaskan hokum-hukum syari'at-NYa. Tetapi bagi meraka yang tidak ingin melakukan Ijtiha, berfatwa, dan tidak akan memutuskan suatu hokum perkara di tengahtengah masyarakat, maka bagi mereka ada dua hukum :

a. Bagi orang yang berilmu ('alim) tidak mesti baginya untuk belajar ilmu mqashid syari'ah

${ }^{41}$ Syathibi, 409-410) 
dikenai hokum fardhu 'ain, akan tetapi baginya wajib kifayah. Kenapa tidak fardhu 'ain baginya apalagi dia adalah seorang yang berilmu, disebabkan karena tidak semua untuk berijtihad dengan menggali dalil-dalil tertentu tetapi baginya cukup berfatwa jika memang punya kemampuan dalam hal itu. Oleh sebab itu, hukum mempelajari ilmu ini bukan bagian dari fardhu 'ain.

b. Orang awam ('amy) tidak termasuk baginya kedua hukum di atas, tidak dikenai fardhu 'ain juga tidak dikenai fardhu kifayah (wajib kifayah). Karena tidak semua orang mukallaf (orang yang dibebani kewajiban) butuh mengerti dan faham terhadapp maqashid syari'ah sebab ilmu maqashid syari'ah bagian dari ilmu yang perlu pemahaman yang sangat mendalam. Bagi orang awam, cukup tahu macam-macam hukum dan tidak wajib baginya tahu dan mengerti maqashid hukumhukum tersebut. $^{42}$

\section{Titik temu Politik Hukum Islam dan Maqashid Syariah}

Hubungan antara politik hukum Islam denganMaqashid Syariah kaitannya sangat erat sekali, karena tujuan dari maqashid syariah itu sendiri adalah untuk mencapai mashlahah, sedangkan tujuan politik hukum Islam adalah mengatur ummat manusia demi kemaslahatan bersama. Titik temunya pada konsep maslahah.

\footnotetext{
42 Abdul Aziz bin Abdurrahman, Ilmu Maqashid Syari'ah, (Riyadh : Maktabah Malik Fahd, 2002), hln 47
}

Para ahli fiqh Islam membagi cakupan lingkup wilayah pembahasan fiqh (kaitannya dengan ijtihad) menjadi dua,yaitu muamalah dan ibadah. Ruang ijtihad di bidang muamalah lebih luas daripada bidang ibadah yang sifatnya ta'abbudi. Tujuan dan kandungan utama dalam Syariah Islam ialah Maslahah itu sendiri. Bahkan para Ulama' seperti Imam Al-Ghazzali, Asy-Syathibi dan lain-lain, telah merumuskan bahwa tujuan Syariah Islam itu mendatangakan kemaslahatan dan menolak kerusakan.

Dinamika sosial politik tidak hanya tampak dari semangat otonomi daerah yang cukup tinggi, tetapi juga ditandai dengan munculnya berbagai partai politik, baik berkarakter agama, netral agama atau lintas agama. Tentu halini telah mempengaruhi perjalanan politik Islam. Partai yang bernuansa religius terlihat membawa pesan-pesan agama meskipun nuansa politik terlihat juga tidak bisa dielakkan. Partai-partai yang berbasis agama meski cenderung dominan politik, namun perjuangan keagamaannya tidak dapat ditepis, dan salah satu misi perjuangan yang sering tampak ke permukaan adalah munculnya ide untuk penyusunan Perda yang memiliki nuansa hukum Islam.

Kemunculan Perda syariah adalah upaya menunjukkan bahwa agama Islam adalah agama yang rahmatan lil'alamin responsif terhadap kebutuhan dan keinginan masyrakat terhadap penerapan syariah Islam. Dengan 
AL-IMARAH: Jurnal Pemerintahan dan Politik Islam Vol. 4, No. 1, 2019

demikian, antara politik hukum Islam dan Maqashid syariah akan bertemu pada titik tekan kemaslahatan berbangsa dan bernegara.

\section{Penutup}

Politik hukum Islam sebagai pedoman dasar yang bertujuan untuk memperbaiki kehidupan umat dan memberikan ketentuanketentuan hukum untuk mencapainya. Adab sebagai politik hukum Islam menjadi instrumen penting untuk mengatur kehidupan umat manusia agar terarah untuk menuju jalan yang diridhai Allah SWT. Politik hukum Islam merupakan bentuk wujud riil dari Islam sebagai agama wahyu yang mempersatukan nilai-nilai dalam kehidupan manusia. Umat Islam secara mendunia bersatu dalam memahami hukum Islam sebaagi nilai-nilai kehidupan manusia yang bertujuan mulai untuk mencapai keselamatan dunia dan akhirat.

Konsep Maqashid syariah dalam politik hukum Islam intinya adalah gerak aktivitas yang berdasarkan ubudiyyah dan muamalah. Hukum Islam sebagaimana yang terdapat dalam alQur'an dan al-Hadis merupakan pranata kehidupan luhur umat manusia mencapai kebaikan kehidupan. Ketika umat manusia telah menerima Islam sebagai agama, maka mereka menerima otoritas hukum Islam terhadap dirinya. Bagi umat Islam, hukum Islam adalah kehendak dan tatanan yang bersumber langsung dari Allah SWT melalui Nabi Muhammad SAW yang selanjutnya dikembangkan oleh para 80 ulama. Hal inilah yang membedakan dengan hukum Barat, hukum Islam bukanlah hasil karya yang gradual dari manusia, tetapi merupakan ketentuan yang bersumber langsung dari Allah SWT.

Maqashid syariah sebagai konsep politik hukum Islam pada dasarnya merupakan sikap hidup yang tujuan terakhirnya adalah kedekatan spiritual kepada Allah SWT, sehingga adab juga dikaitkan dengan hukum-hukum syariat dan tauhid. Manusia beradab menyadari sepenuhnya tanggung jawab dirinya kepada Allah SWT dengan memahami, menunaikan dan meningkatkan setiap aspek dirinya menuju kesempurnaan hidup.

Politik hukum Islam dan maqashid syariah memiliki tujuan yang sama yaitu menjadi pengaturan kepentingan hidup manusia, yang sesuai dengan dasarnya dalam nas AlQur'an maupun al-hadits. Ia adalah pengurusan hal-hal yang bersifat umum bagi negara Islam dengan cara menjamin perwujudan kemaslahatan dan menghindari kemadaratan (bahaya) dengan tidak melampaui batas-batas syari'ah dan pokok-pokok syari'ah yang bersifat umum, sesuai dengan pendapat ulama-ulama Mujtahid.

\section{Pustaka Acuan}

Afifuddin Muhajir. Fiqh Tata Negara. (Yogyakarta, IRCiSoD : 2017) 
Abdul Aziz bin Abdurrahman. Ilmu Maqashid Syari'ah. (Riyadh : Maktabah Malik Fahd, 2002)

Abdul Aziz bin Abdurrahman. Ilmu Maqashid Syari'ah. (Riyadh : Maktabah Malik Fahd, 2002)

Abu Hamid Muhammad bin Muhammad alGhazali. Al-Mustasfa min 'Ilm al-Usul. (Beirut: Mu'assasat al-Risalah, 1417 H/1997 M)

Abu Ishaq Ibrahim al-Syathibi. Al-Muwafaqat fi Usul al-Syari'ah. (Beirut: Dar al-Fikr, $1341 \mathrm{H})$

Ahmad Syafi'i Ma'arif. Islam dan Masalah Kenegaraan. (Jakarta: LP3S, 1996)

Al-Fayumi. Al-Misbahul Munir li Gharibi syarhil kabir li ar-rafi'i. (Beirut : Maktabah Lubnan, 1987

Asafri Jaya. Konsep Maqashid. .bisa dilihat: Mahmud Syaltout, Islam: 'Aqidah wa Syari'ah. (Kairo: Dar al-Qalam,1966)

E. Utrecht. Pengantar dalam Hukum Indonesia. Cetakan Kesembilan, (Jakarta Penerbitan Universitas : 1966)

Fazlur Rahman. Islam, alih bahasa: Ahsin Muhammad. ( Bandung: Pustaka, 1994)
Ichtiyanto. "Pengembangan Teori Berlakunya Hukum Islam di Indonesia, " dalam Juhaya S.Praja. Hukum Islam di Indonesia Perkembangan dan Pembenmtukan. (Bandung:P.T. Remaja Rosdakarya, 1991)

Imam Syaukani dan Ahsin Tohari. Dasar-Dasar Politik Hukum. (Jakarta: Raja Grafindo : 20013)

Jazim Hamidi,dkk. Teori dan Politik Hukum Tata Negara. (Yogyakarta, Total Media :2009)

Kamsi. Politik Hukum Islam pada masa Orde Baru. Diunduh pada tanggal 10-11-2018 pada jam 10 pagi. Lihat juga di Ichtiyanto, "Pengembangan Teori Berlakunya Hukum Islam di Indonesia," dalam Juhaya S.Praja, Hukum Islam di Indonesia Perkembangan dan Pembenmtukan. (Bandung:P.T. Remaja Rosdakarya, 1991)

Mahfud MD. Politik Hukum di Indonesia. (Jakarta: Rajawali Perss, 2011)

Marzuki Wahed dan Rumadi. Fiqh Madzhab Negara. (Yogyakarta, LkiS : 2011)

Mhd Halkis. Konstelasi Politik Indonesia: Pancasila dalam Analisis Fenomenologi Hermeneutika. (Jakarta, Yayasan Pustaka Obor Indonesia : 2017)

Moh. Mahfud MD. "Perkembangan Politik hukum: Studi tentang Pengaruh Konfigurasi Politik terhadap Produk hukum di 
AL-IMARAH: Jurnal Pemerintahan dan Politik Islam

Vol. 4, No. 1, 2019

Indonesia, disertasi dalam ilmu hukum pada

UGM. (Yogyakirta: tidak diterbitkin, 1993)

Muhammad Abu Zahrah. Ushul al-Fiqh.

(Beirut: Dar al-Tsaqafah, Tt.)

Mustafa. Hukum Islam Kontemporer. (Jakarta: Sinar Grafika, 2009)

Nasution, Harun. Islam Ditinjau dari Aspeknya. Jilid I dan II (Jakarta: UI-Press, 1979)

Regen,B.S. Politik Hukum. (Bandung

Utomo Press : 2006)

Sajipto Rahardjo. Ilmu Hukum. (Bandung: Citra Aditya Iakti : 2001)

Samih Abdul Wahab al-Jundi. Ahammiyatul Maqashid fi Syariah alIslamiyah. (Beirut: Ar-Risalah, 2008),

Sri Lum'atus Sa'adah. Peta Pemikiran Fiqih Progresif. (Jember: STAIN Jember Press, 2011)

Syamsuddin Ramadhan. Menegakkan Kembali Khilafah Islamiyah. (Jakarta: Panjimas, 2003)

Toha Jabir al-Wani. Maqashid asySyari'ah. (Beirut : Dar al-Hadi, 2001)

Warkum Sumitro, dkk. Politik Hukum Islam. (Malang, UB Press : 2014 )

William Zevenbergen dalam Abdul Latif dan Hasbi Ali. Politik Hukum. (Jakarta, Sinar Grafika: 2011)

Yusuf Qardhawi. Siyasah al-Syar'iyyah fi Dzau'i nushusi al-Syari'ah we maqashidiha. (Cairo, Maktabah Wahbah, 2008)
Ahmad Fathi Bahansi. Al Siyasah al Jinayah fi al Syari'ah al Islamiyah. (Beirut, Dar al Arubah : 2001)

Dr. Akram Kassab. Al Siyasah al Syar'iyyah, Mabadi' wa Mafahim, Dhawabith wa Mashadir. Makalah Jurnal Online International Union for Muslem Scholars (IUMS) dari website http://iumsonline.org/ar/2/b9/ diakses pada tanggal 12 November 2018.

Taqiyuddin al-Nabhani. Sistem Pemerintahan Islam; Doktrin, Sejarah dan Realitas Empiri. Cet. I (Bangil; Al-Izzah, 1996) 